\title{
2. Chiniot of Bābar's First Campaign in India.
}

Belfast, Oct. 27, 1898.

Dear Sir,-In Mr. Beames' article on "The Geography of the Kandahár Inscription" in the Society's Journal for October, 1898, after eiting the references in Bābar's Memoirs, pp. 254, 255, to the countries of Behrah, Khushab, Chenāb, and Chaniūt, he identifies the last of these places (at p. 804) with "Chiniot, a town on the Ravi near Gugaira," and interprets Bābar's reference to it as meaning the Rechna Duāb.

Chiniot is not on the Ravi, but on the Chenāb, and is fully sixty miles from Gugaira, and about fifty miles from Bhera, which is almost due north of it. It is still a wellknown town, and is the headquarters of a revenue subdivision (tahsīl) of the Jhang district. It will be found under the name of Chanyot in the map of the Panjab illustrating Alexander's campaign, opposite p. 104 of Cunningham's "Ancient Geography of India," and as Chandanvati in the following map; and a rocky hill near it is mentioned at p. 183. In an enumeration of old cities of the Panjab in the Archaeological Survey Report for 1872-3, at p. 94, Cunningham includes Sodra, Chaniot, and Shorkot on the Chenāb.

It was while on his way across the Salt Range to Bhera in February, 1519 A.D., that Bābar mentioned these countries, "among which" he "now was" (Dowson's Elliot, M.H., iv, 232), and which he desired to recover, as they had been in the possession of Sultan Mas'ūd Mirza, ruler of Kabul and Zabul. He appears to have meant the districts which were within easy reach of the fort of Bhera, and could be controlled by a force stationed there; and the mention of Chiniot indicates that the country in that neighbourhood, on both banks of the Chenāb, was included. Some part of the Rechna Duāb (between the Chenāb and Ravi rivers) would thus be included, but probably not a very large part; and the country adjoining the Ravi, as well as the Upper 
Rechna Duāb, could hardly be referred to, as they would naturally be controlled by the garrison of Lahore.

From the positions of Bhera, Khushab, and Chiniot it may fairly be inferred that the Chenāb country embraced the greater part of the Lower Chaj Duāb, except so far as this was included in the other three countries named. But as Khushab is only about forty miles in a straight line from Bhera, its territory can scarcely be said to comprise the southern part of the Sind Sägar Duāb. At most it would represent the middle part of that Duāb, and probably it would not extend right across it to the Indus.

In the same article, at p. 801 , last line, a comma is apparently omitted between Shor and Patan Shaikh Farid. Shor appears to be Shorkot, north of the confluence of the Ravi and the Chenāb; while Patan Shaikh Farīd is the place now known as Pāk Patan, the ancient Ajudhan, near which there was an important ferry over the Satlej (see Cunningham, "Ancient Geography of India," p. 218).Yours truly,

To the Secretary of the Royal Asiatic Society.

D. G. BARKLeY.

\section{Pedro Teixetra on the Veddas of Ceylox.}

DeAr Sir,--None of the many writers on the Veddas of Ceylon seems to have called attention to what is, apparently, the earliest reference by a European writer ${ }^{1}$ to these "wild men of the woods." This occurs in cap. $\operatorname{xxxv}$ of Pedro Teixeira's Relaciones, ${ }^{2}$ where, in one of his many digressions from the subject of his book, he refers to Ceylon, its products, etc. After speaking of cinnamon, he proceeds :-

"And before leaving the forests where it [the cinnamon] grows in the same Island of Seylan, I shall relate the custom of a certain race that lives in them which is worthy of being known: these barbarians are called Pachas, and dwell naked in the thickets and

I I exclude the Greek and Latin authors quoted by Tennent, as their references are doubtful, to say the least.

2 See R.A.S. Journal for 1897, pp. 624-628, 933-939. 